\title{
PEMENUHAN KEWAJIBAN PENGGUNA JASA SESUAI KONTRAK
}

\author{
Sandi Andika Surya Putra ${ }^{1}$ dan Sarwono Hardjomuljadi ${ }^{2}$
}

\author{
1Prodi Teknik Sipil, Universitas Tarumanagara, Jl. Letjen S. Parman No 1, Jakarta, 11440 \\ Email korespondensi: sandikasuryaputra@yahoo.com \\ ${ }^{2}$ Prodi Teknik Sipil, Universitas Mercu Buana, Jl. Raya Meruya Selatan, Jakarta, 11650 \\ Email : sarwonohm2@yahoo.co.id
}

\begin{abstract}
ABSTRAK
Penggunaan standar kontrak FIDIC sebagai model kontrak konstruksi di Indonesia semakin meningkat. Proyek konstruksi yang didanai oleh swasta, pemerintah maupun pinjaman luar negeri banyak menggunakan standar kontrak FIDIC. Penelitian ini bertujuan untuk memperoleh informasi variabel dominan kewajiban pengguna jasa yang tidak dipenuhi dan dampak yang dapat terjadi apabila tidak dipenuhi. Program penelitian ini menggunakan analisis faktor untuk mendapatkan variabel dominan kewajiban pengguna jasa yang tidak dipenuhi, dan selanjutnya dilakukan analisis data dengan menggunakan analisis kualitatif. Hasil analisis didapat 5 variabel dominan yaitu 1) Pengguna jasa memberikan ganti rugi atas setiap biaya ditambah dengan keuntungan, yang akan ditambahkan ke dalam harga kontrak jika pengujian ditunda oleh pengguna jasa, 2) Pengguna jasa membayar jumlah yang disahkan dalam setiap Berita Acara Pembayaran Sementara, 3) Pengguna jasa memberikan perpanjangan waktu penyelesaian pekerjaan akibat dari penghentian pekerjaan oleh kontraktor yang dikarenakan pengguna jasa gagal untuk menerbitkan dan mensahkan Berita Acara Pembayaran Sementara, keterlambatan pembayaran progres pekerjaan, 4) Pengguna jasa memberikan perpanjangan waktu jika pengujian ditunda oleh pengguna jasa, 5) Pengguna jasa memberikan ganti rugi biaya bunga yang digabungkan secara bulanan pada pembayaran yang tertunda selama terjadinya keterlambatan pembayaran. Dampak yang terjadi apabila kewajiban pengguna jasa sesuai kontrak tidak dipenuhi adalah 1) Penyedia jasa akan mengeluarkan biaya yang tidak diperkirakan sebelumnya, 2) Gagal bayar kontraktor utama kepada sub-kontraktor, 3) Penyedia jasa berpotensi terkena denda yang di ajukan oleh pengguna jasa akibat mundurnya jadwal pelaksanaan proyek, 4) Berpotensi menimbulkan dispute.
\end{abstract}

Kata kunci: Pemenuhan Kewajiban, Pengguna Jasa, Kontrak

\begin{abstract}
ABSTRACT: Application FIDIC General Condition of Contract as a model for construction contract in Indonesia is increased. Constuction project's funded by goverment, private, or foreign loan using FIDIC General Condition of Contract. This study aims to obtain information on the dominant variable of employer obligations that are not fulfilled and the impacts that may occur if not fulfilled. Research program use factor analysis to obtain the dominant variable that the employer are not fulfilled, and then analyzed the data using qualitative analysis. The result showed obtained five dominant variables is 1) The employer provide compensation of any cost plus reasonable profit, which shall be included in the contract price if testing is delayed by the employer, 2) The employer pay the amount certified in each Interm Payment Certificate, 3) The employer provide an extension of the time for completion of work as a result of work termination by the contractor due to the employer failing to issue and validate Interm Payment Certificate, delay payments for work progress, 4) The employer provide an extention of time if testing is delayed by the employer, 5) The employer provide compensation of financing charges compounded monthly on the amount unpaid during the period of delay employer. The impact that can occur if the employer obligations according to the contract are not fulfilled are 1) The contractor will incur costs that are not predicted before, 2) Sub-contractors unpaid by main-contractor, 3) The employer has the potential to claims fines from the contractor for delays in the project schedule, 4) Potential dispute.
\end{abstract}

Keywords: Implementation of Obligations, Employer, Contract 


\section{PENDAHULUAN}

Industri konstuksi merupakan salah satu faktor penyumbang pertumbuhan ekonomi di Indonesia. Hal ini dibuktikan berdasarkan data Badan Pusat Statistik tahun 2019, kontribusi industri konstruksi terhadap perekonomian Indonesia cukup besar yaitu 10,76\% terhadap Produk Domestik Bruto (PDB) Indonesia pada triwulan I tahun 2019 [1]. Proyek konstruksi muncul karena adanya permintaan yang berasal dari berbagai industri seperti perbankan, pertambangan, teknologi, dan berbagai jenis jasa. Namun tidak menutup kemungkinan permintaan tersebut muncul dari pelaku industri konstruksi itu sendiri. Selain dari segi permintaan, dari segi investasi pengembangan proyek konstruksi juga sangat berkaitan dengan industri lain misalnya dalam hal pendanaan.

Industri kontruksi merupakan salah satu industri yang sangat berisiko karena memiliki karakteristik atau ciri khas yang berbeda dari masing-masing proyek konstruksi [2]. Selain itu industri konstruksi juga memiliki faktor risiko dengan tingkat ketidakpastian yang lebih tinggi dibandingkan dengan industri lainnya [3]. Risiko dapat diidentifikasi dan diklasifikasi, hal ini dapat membantu tim proyek menyusun berbagai risiko yang dapat mempengaruhi suatu proyek konstruksi. Pengklasifikasian risiko dapat berkontribusi pada efektivitas dan kualitas proses identifikasi risiko dan menciptakan pemahaman yang lebih baik tentang sifat risiko dan sumbernya [4]. Dalam studinya Siraj dan Aminah [5] menyederhanakan kategori risiko pada industri konstruksi menjadi 10 risiko yang dapat terjadi, yaitu manajemen, teknis, konstruksi, sumber daya, kondisi lapangan, hukum dan kontrak, ekonomi dan keuangan, sosial, politik dan Health, Safety and Environment (HSE).

Pada proses pelaksanaannya proyek konstruksi memiliki tingkat keunikan dan kompleksitasnya masing-masing dan dapat menimbulkan berbagai risiko salah satunya risiko hukum dan kontrak. Untuk mengurangi dampak risiko tersebut, maka perlu adanya sebuah ikatan kerja antara pengguna jasa dengan penyedia jasa yang digunakan sebagai dasar hukum, berbentuk kontrak konstruksi. Di Indonesia, kontrak konstruksi yang sering dipergunakan antara lain, yaitu: Peraturan Presiden Nomor 54 Tahun 2010 \& Peraturan Presiden Nomor 70 Tahun 2012, Fédération Internationale Des Ingenieurs-Conseils (FIDIC), Joint Contract Tribunals (JCT), American Institute of Architects (AIA), Singapore Institute of Architects (SIA) [6]. Kontrak konstruksi didefinisikan sebagai kontrak yang mengikat dua atau lebih pihak (biasanya Pengguna Jasa dan Penyedia Jasa) pada seperangkat kondisi (umum dan khusus), kebijakan dan klausal yang diputuskan oleh Penyedia Jasa, disetujui oleh kedua belah pihak dan tercatat dalam kontrak [7]. Di dalam syarat-syarat kontrak konstruksi berisikan hak dan kewajiban dari masingmasing pihak yang terkait dalam kontrak.

Namun sayangnya sudah menjadi rahasia umum, jika para pihak seringkali melihat kontrak kerja konstruksi hanya sekilas dicermati tentang "nilai kontrak" dan "tanda tangan" [8]. Jarang sekali para pihak mencermati hal-hal apa yang seharusnya dimuat di dalam suatu kontrak.

Berdasarkan hal tersebut diatas merupakan hal yang lazim apabila terjadi klaim dalam proyek konstruksi. Klaim dapat terjadi saat satu pihak percaya bahwa pihak lain belum memenuhi kewajiban yang diperjanjikan dalam kontrak dan mereka layak memperoleh kompensasi berupa uang dan/atau waktu. Tidak dipenuhinya kewajiban sesuai kontrak, dapat disebabkan adanya pelanggaran yang disadari oleh pihak yang melanggar atau dapat juga disebabkan karena masing-masing pihak yang terikat kontrak tidak memahami dengan baik setiap kata dalam kontrak [9]. Jika permasalahan dan klaim itu tidak bisa diselesaikan maka dapat memunculkan sengketa (dispute). Dari uraian tersebut di atas, maka perlu adanya penelitian tentang apa saja kewajiban pengguna jasa sesuai dengan kontrak. Agar nantinya terlihat jelas pihak mana yang telah memenuhi 
kewajibannya sesuai kontrak dan pihak mana yang tidak memenuhi kewajibannya sesuai kontrak. Rumusan masalah dalam penelitian ini adalah: 1) Apa saja kewajiban pengguna jasa sesuai dengan kontrak yang tidak dipenuhi? ; dan 2) Apa dampak tidak dipenuhinya kewajiban pengguna jasa sesuai kontrak?. Tujuan dari penelitian ini adalah untuk memperoleh informasi: 1) Kewajiban pengguna jasa sesuai dengan kontrak yang tidak dipenuhi; dan Dampak tidak terpenuhinya kewajiban pengguna jasa sesuai kontrak.

\section{PROYEK KONSTRUKSI}

Proyek konstruksi adalah suatu kegiatan sementara yang berlangsung dalam jangka waktu terbatas, dengan alokasi sumber daya tertentu dan dimaksudkan untuk melaksanakan tugas yang sasarannya telah digariskan dengan jelas [10]. Selain itu, menurut Ervianto (2005) [11] proyek konstruksi merupakan suatu rangkaian kegiatan yang hanya satu kali dilaksanakan dan umumnya berjangka waktu pendek. Sedangkan menurut Undang-Undang No.2 Tahun 2017 Pasal 1 tentang Jasa Konstruksi mendefinisikan proyek konstruksi merupakan keseluruhan atau sebagian kegiatan yang meliputi pembangunan, pengoperasian, pemeliharaan, pembongkaran, dan pembangunan kembali suatu bangunan. Dari berbagai definisi diatas dapat disimpulkan bahwa proyek konstruksi merupakan suatu kegatan sementara yang berlangsung dalam jangka waktu terbatas, dengan alokasi sumber daya tertentu untuk mendapatkan hasil konstruksi dengan standar mutu yang baik.

Dalam melaksanakan suatu proyek konstruksi ada parameter yang harus dipenuhi untuk menjamin keberhasilan penyelenggaraan proyek konstruksi yaitu besar biaya (anggaran) yang dialokasikan, jadwal, serta mutu yang harus dipenuhi [10]. Ketiga hal tersebut sering diasosiasikan sebagai sasaran proyek atau umumnya disebut sebagai Triple constraint. Parameter tersebut dapat diilustrasikan seperti Gambar 1.

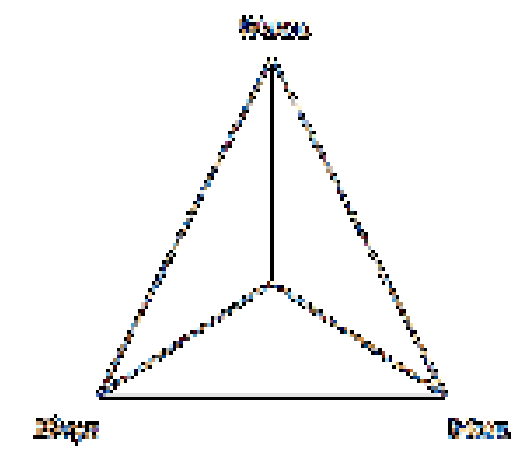

Gambar 1. Triple Constraint [10]

\section{Jenis-jenis proyek konstruksi}

Secara umum ada berbagai jenis proyek konstruksi dan dapat dibedakan menjadi tiga jenis yaitu: 1) konstruksi bangunan hunian, 2) konstruksi bangunan non-hunian, dan 3) konstruksi non-bangunan [12]. Konstruksi bangunan hunian meliputi rumah, kondominium, perumahan multi unit, serta low rise dan high rise apartment. Konstruksi bangunan non-hunian meliputi bangunan yang didirikan untuk tujuan komersil dan industrial seperti pertokoan, gedung perkantoran, gudang, fasilitas manufaktur, rumah sakit, stasiun, pusat perbelanjaan, bangunan untuk pendidikan, dan bangunan institusional (bank, gereja, panti jompo, dan lain-lain).

Konstruksi non-bangunan dibedakan menjadi tiga bagian yaitu: 1) konstruksi berat dan jalan raya, 2) konstruksi perairan, 3) konstruksi militer [12].

\section{Kontrak}

Menurut Gifis [13] kontrak merupakan suatu perjanjian, atau serangkaian perjanjian dimana hukum memberikan ganti rugi terhadap wanprestasi terhadap kontrak tersebut, atau terhadap pelaksanaan kontrak tersebut oleh hukum dianggap sebagai suatu tugas. Sedangkan menurut Garner [14] menyatakan kontrak adalah suatu perjanjian anatar dua pihak atau lebih dengan hak dan kewajiban yang 
dapat diberlakukan atau dikenal dalam hukum atau perundangan yang berlaku, atau dapat juga berupa suatu janji atau serangkaian janji-janji oleh para pihak untuk suatu transaksi, yang didasari hukum perundangan yang berlaku.

Berdasarkan berbagai pengertian di atas dapat dilihat beberapa unsur-unsur yang tercantum dalam kontrak yaitu adanya hubungan hukum, danya subjek hukum, dan adanya prestasi. Hubungan hukum merupakan hubungan yang menimbulkan akibat hukum, dimana pengertian akibat hukum yaitu timbulnya hak dan kewajiban. Subjek hukum yaitu pendukung hak dan kewajiban, dimana subjek hukum yang dimaksud adalah subjek hukum yang diatur dalam KUH Perdata yang terdiri dari dua bagian yaitu manusia dan badan hukum. Prestasi menurut Pasal 1234 KUH Perdata terdiri atas untuk memberi sesuatu, untuk berbuat sesuatu, dan untuk tidak berbuat sesuatu.

\section{KONTRAK KONSTRUKSI}

Perjanjian antara dua pihak dalam pelaksanaan konstruksi bangunan maupun infrastruktur bisa disebut sebagai Kontrak Konstruksi. Tetapi Undang-undang Nomor 2 Tahun 2017 Tentang Jasa Konstruksi Pasal 46 menyatakan bahwa pengaturan hubungan kerja antara Pengguna Jasa dan Penyedia Jasa harus dituangkan dalam Kontrak Kerja Konstruksi. Maka selanjutnya perjanjian semacam itu tidak lagi disebut sebagai Kontrak Konstruksi melainkan Kontrak Kerja Konstruksi. Menurut Undangundang Nomor 2 Tahun 2017 Pasal 1 angka 8, Kontrak Kerja Konstruksi didefinisikan sebagai keseluruhan dokumen kontrak yang mengatur hubungan hukum antara Pengguna Jasa dan Penyedia Jasa dalam penyelenggaraan Jasa Konstruksi.

Kontrak konstruksi timbul karena adanya kontraktor yang berjanji akan melakukan pekerjaan dan pengguna jasa yang memanfaatkan jasa kontraktor dan berjanji akan membayar apa yang dikerjakan oleh kontraktor yang sesuai dengan kebutuhan pengguna jasa dengan persyaratan tertentu yang harus dipenuhi.

Dari apa yang tercantum di atas, jelas bahwa suatu perjanjian harus ditaati, karena merupakan suatu undang-undang bagi para pihak yang membuatnya (menandatanganinya) yang bersifat mengikat dan memiliki kekuatan hukum yang memuat persetujuan bersama secara sukarela antara pihak kesatu dan pihak kedua.

\section{Jenis-jenis kontrak konstruksi}

Menurut Keppres No. 80 Tahun 2003 [14] adapun jenis-jenis kontrak konstruksi adalah:

1. Berdasarkan bentuk imbalan: a) Lump Sum; b) Harga satuan/unit price; c) Gabungan Lump sum dan harga satuan; d) Terima jadi (turn key); e) Persentase.

2. Berdasarkan jangka waktu pelaksanaan: a) Tahun tunggal; b) Tahun jamak.

3. Berdasarkan jumlah pengguna/jasa: a) Kontrak pengadaan tunggal; b) Kontrak pengadaan bersama

\section{Tahap pelaksanaan kontrak konstruksi}

Menurut Peraturan Presiden No. 29 Tahun 2000 [15] tentang penyelenggaraan jasa konstruksi lingkup tahapan perencanaan pekerjaan konstruksi terbagi menjadi beberapa tahapan antara lain prastudi kelayakan, studi kelayakan, perencanaan umum, dan perencanaan teknik, namun tahapan-tahapan tersebut tergantung seberapa besar risiko yang akan terjadi. Dalam pemilihan tahapan-tahapan perencanaan pekerjaan konstruksi menurut Peraturan Presiden No. 29 Tahun 2000 pasal 26 menyatakan bahwa apabila pekerjaan konstruksi dengan risiko tinggi harus dilakukan prastudi kelayakan, studi kelayakan, perencanaan umum, dan perencanaan teknik. Sedangkan pekerjaan konstruksi dengan risiko sedang harus dilakukan studi kelayakan, perencanaan umum, dan perencanaan teknik. Untuk 
risiko rendah hanya dilakukan perencanaan teknik saja.

Tahap selanjutnya setelah dilakukan perencanaan adalah tahap melaksanakan apa yang direncanakan sekaligus mengawasinya. Menurut Peraturan Presiden No. 29 Tahun 2000 pasal 28 lingkup tahap pelaksanaan beserta pengawasan pekerjaan konstruksi meliputi pelaksanaan fisik, pengawasan, uji coba, dan penyerahan hasil akhir pekerjaan. Dalam proses pelaksanaan beserta pengawasan pekerjaan konstruksi haruslah dilakukan berdasarkan hasil perencanaan teknik. Oleh karena itu setiap bangunan gedung negara harus memenuhi persyaratan administratif baik pada tahap pembangunan maupun pada tahap pemanfaatan bagunan gedung. Skema tahapan-tahapan pelaksanaan kontrak konstruksi dapat dilihat pada Gambar 2 berikut.

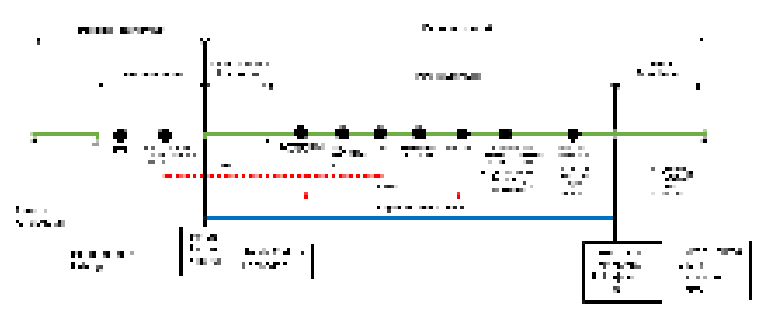

Gambar 2. Tahap Pelaksanaan Kontrak [16]

\section{Persyaratan kontrak}

Persyaratan adalah bagian pokok dari suatu kontrak yang mengarah pada karakteristik dari suatu kontrak. Pelanggaran persyaratan memberikan hak kepada pihak yang dicederai untuk tidak mengakui kontrak dan mengajukan klaim ganti rugi [17]. Sedangkan menurut Garner [18] persyaratan adalah suatu kejadian mendatang dan tidak pasti dimana keberadaan atau batas suatu kewajiban atau tanggung jawab tergantung padanya; suatu tindakan atau kejadian yang tidak pasti yang menambah atau meniadakan suatu kewajiban menghasilkan kinerja yang dijanjikan. Sebagai contoh, jika Ahmad menjanjikan Rp 500.000,- kepada Ali sebagai pembayaran untuk perbaikan mobilnya tetapi Ali gagal memperbaikinya, maka Ahmad dibebaskan dari kewajiban membayar [9].

Dalam persyaratan suatu kontrak menurut Bubshait and Soliman [19] haruslah: Clarity, Conciseness, Completeness, Internal consistency, External consistency, Practically, Fairness, Effect on quality, Effect on cost, Effect on schedule, Effect of safety.

\section{Model kontrak konstruksi di Indonesia}

Kontrak konstruksi disepakati sebagai hasil dari proses penawaran dan negosiasi antara pengguna jasa dan penyedia jasa. Formalisasi kontrak dilakukan melalui suatu dokumen tertulis yang menjelaskan hak dan kewajiban masing-masing pihak yang terikat didalamnya. Hingga pertengahan tahun 1999, Indonesia belum memiliki peraturan perundang-undangan yang baku mengenai Jasa Konstruksi. UU No. 18/1999 tentang Jasa Konstruksi bari dijadikan Undang-Undang pada tahun 1999 dan baru mulai diberlakukan pada tahun 2000, dengan demikian terdapat banyak sekali model kontrak konstruksi di Indonesia. Namun, secara umum model kontrak tersebut dapat dikelompokkan menjadi 3 golongan yaitu:

\section{Versi Pemerintah}

Biasanya masing-masing Kementerian memiliki suatu standar sendiri. Standar yang dipakai adalah Standar Kementerian Pekerjaan Umum.

2. Versi Swasta Nasional

Versi ini beraneka ragam sesuai selera pengguna jasa. Terkadang mengutip standar Kementerian atau mengutip kontrak luar negeri seperti FIDIC, JCT, atau AIA. Namun karena diadopsi secara sebagian tersebut, maka wajah kontrak versi ini menjadi tidak jelas dan sangat rawan sengketa.

3. Versi Swasta Asing

Umumnya digunakan oleh pengguna jasa/pemilik proyek asing yang mengadopsi standar kontrak FIDIC, JCT atau AIA 


\section{FIDIC condition of contract for construction tahun 1999}

Standar Kontrak FIDIC Buku Merah (Red Book) digunakan untuk pekerjaan yang dirancang oleh pemberi kerja atau konsultan proyek dan dilaksanakan oleh kontraktor melalui lingkup kerja yang ditentukan. Namun, ruang lingkupnya dapat mencakup beberapa paket pekerjaan yang perlu dirancang dan dibangun oleh kontraktor dibawah pengawasan supervisor dari pemberi kerja.

\section{Urutan dokumen kontrak menurut FIDIC}

Dalam kontrak konstruksi atau perjanjian antara pengguna jasa dan penyedia jasa terdiri dari beberapa dokumen yang saling melengkapi dan secara bersama disebut dokumen kontrak. Dokumen kontrak suatu proyek menurut FIDIC General Conditions of Contracts 1999 (Red Book) Sub-klausal 1.5 dapat terdiri dari [20]:
1. Perjanjian
kontrak
(Contract Agreement)
2. Surat penunjukan (Letter of Acceptance)
3. Surat penawaran (Letter of Tender)
4. Persyaratan khusus (Particular Conditions)

5. Persyaratan umum (General Conditions)

6. Spesifikasi (Specification)

7. Gambar-gambar (Drawings)

8. Jadwal/daftar (Schedules)

9. Appendix to Tender

10. Bill of Quantity and Day Work Schedule

\section{KLAIM KONSTRUKSI}

Menurut Garner [18] klaim adalah suatu tuntutan atas uang, kepemilikan atau suatu pemulihan hukum yang berhak didapatkan seseorang. Selain itu menurut Hardjomuljadi et al [21] klaim adalah suatu tindakan seseorang untuk meminta sesuatu yang mana hak seseorang tersebut telah hilang sebelumnya karena yang bersangkutan beranggapan memiliki hak untuk mendapatkannya kembali. Menurut
Martin and Law [22] klaim adalah suatu tuntutan atas suatu ganti rugi atau memastikan suatu hak, terutama hak untuk membawa kasus tertentu ke pengadilan.

Dari pernyataan diatas jelas bahwa klaim dapat timbul kapan pun dan dapat terjadi karena berbagai alasan. Berdasarkan penelitian yang dilakukan oleh Hardjomuljadi [9] pengajuan klaim konstruksi berdasarkan sudut pandang pengguna jasa yaitu perubahan disain, perbedaan intepretasi kontrak, perubahan lingkup pekerjaan, keterlambatan penyelesaian pekerjaan oleh kontraktor, pekerjaan tambah (Variation order), pengambilan keputusan yang lambat oleh kedua belah pihak. Sedangkan pengajuan klaim konstruksi berdasarkan sudut pandang penyedia jasa yaitu perubahan disain, keterlambatan pembayaran, manajemen dan pengawasan yang buruk, perubahan lingkup pekerjaan, kondisi yang tidak dapat ditentukan sebelumnya, kebijakan pemerintah, perbedaan intepretasi kontrak, pengambilan keputusan yang lambat oleh kedua belah pihak, instruksi pekerjaan tambah secara lisan oleh pengguna jasa. Selain itu timbulnya klaim konstruksi menurut kontraktor dikarenakan pengguna jasa tidak memenuhi kewajiban yang diperjanjikan dalam kontrak, sebaliknya pihak pengguna jasa mengajukan klaim kepada kontraktor dengan alasan kontraktor tidak memenuhi kewajibannya sesuai kontrak. Tidak dipenuhinya kewajiban sesuai kontrak, dapat disebabkan adanya pelanggaran yang disadari oleh pihak yang melanggar atau dapat juga disebabkan karena masingmasing pihak yang terikat kontrak tidak memahami dengan baik setiap kata dalam kontrak. Terjadinya klaim yang kemudian berkembang menjadi sengketa terutama seringkali disebabkan oleh kelalaian, kekurang telitian, dan kelemahan dalam pengetahuan kontraktual para pelaku jasa konstruksi [23].

Klaim konstruksi dapat berdampak pada bertambahnya harga kontrak di samping karena adanya perubahan desain yang 
mengakibatkan bertambahnya volume pekerjaan dan perpanjangan waktu penyelesaian. Menurut Hardjomuljadi [23] komponen penambahan harga kontrak dapat diklasifikasikan menjadi tiga kelompok, yaitu perintah perubahan (variation order), penyesuaian harga dengan rumus eskalasi (price adjustment), dan klaim.

Suatu hal yang harus dipahami dalam kaitannya dengan klaim adalah kontraktor selalu berkewajiban menginvestasikan sumber daya, terutama sumber daya keuangan untuk menyelesaikan pekerjaan sehingga kontraktor akan selalu berupaya sekuat tenaga untuk memperoleh kembali dana investasi tersebut sebelum atau pada akhir penyelesaian pekerjaan.

\section{JENIS PENELITIAN}

Berdasarkan teknik pengumpulan data, penelitian ini termasuk penelitian kualitatif yang dilengkapi dengan penelitian kuantitatif dengan jenis penelitian survei. Selanjutnya antara penelitian kualitatif dan kuantitatif dilakukan penggabungan sehingga dapat disebut mixed method [24]. Penelitian dilakukan pada proyek pembangunan gedung bertingkat di Jakarta.

\section{DATA DAN VARIABEL}

Data yang digunakan dalam penelitian ini terdiri dari 2 (dua) jenis data, yaitu data primer dan data sekunder. Data primer dalam penelitian ini didapat melalui penyebaran kuisioner kepada pihak-pihak yang terkait dalam suatu proyek konstruksi. Kuisioner terdiri dari variabel-variabel yang didapat dari studi literatur tentang standar kontrak FIDIC General Conditions of Contracts 1999 (Red Book). Kriteria responden yang ditetapkan dalam penelitian ini adalah responden yang memiliki pengalaman minimal 5 tahun bekerja di bidang konstruksi dan memiliki pengalaman minimal 5 tahun bekerja dalam bidang kontrak konstruksi. Jumlah sampel dalam penelitian ini berjumlah 42 sampel yang terdiri dari pengguna jasa, konsultan, dan kontraktor yang terlibat dalam pembangunan gedung bertingkat tinggi di Jakarta yang menggunakan FIDIC General Conditions of Contracts 1999 (Red Book) sebagai model kontrak.

Data sekunder yang digunakan dalam penelitian ini adalah literatur yang termuat dalam buku-buku, jurnal, dan berbagai media yang berhubungan dengan topik penelitian.

\section{INSTRUMEN PENELITIAN}

Instrumen dalam penelitian ini adalah kuesioner metode tertutup, dimana kuesioner disediakan jawabannya, sehingga responden tinggal memilih dan menjawab secara langsung. kuesioner terdiri dari 37 butir pernyataan. Penyebaran kuesioner dilakukan dengan beberapa cara seperti penyerahan kuisioner secara langsung dan menggunakan google form yang linknya dikirim melalui email atau whatsapp. Skala ukur yang digunakan dalam penelitian ini adalah model skala likert dengan skala 5 . Selain itu, pernyataan pada skala likert yang digunakan mempunyai gradasi positif sampai negatif.

\section{ANALISIS DATA}

Pada penelitian ini metoda analisis data dilakukan dengan analisis kuantitatif dan analisis kualitatif. Analisis kuantitatif dilakukan dengan menggunakan bantuan software IBM SPSS Statistic 26.0 dimana analisis data yang akan dilakukan yaitu uji validitas, uji reliabilitas, dan analisis faktor.

Menurut Sugiyono [25] validitas adalah suatu ukuran yang menunjukkan bahwa variabel yang diukur memang benar-benar variabel yang hendak diteliti oleh peneliti. Sehingga secara umum dapat diartikan bahwa validitas merupakan kekuatan kesimpulan, inferensi, atau proporsi dari hasil penelitian yang sudah dilakukan yang mendekati kebenaran. Suatu hasil pengukuran dikatakan valid apabila pengukuran dilakukan terhadap hal yang 
seharusnya diukur dan inferensi yang dihasilkan mendekati kebenaran.

Reliabilitas merupakan derajat konsistensi dan stabilitas data atau temuan [26]. Hal tersebut menunjukkan bahwa suatu data dikatakan reliabel apabila dua atau lebih peneliti dalam objek yang sama akan menghasilkan data yang sama, atau peneliti yang sama dalam waktu berbeda menghasilkan data yang sama, atau sekelompok data bila terbagi menjadi dua menunjukkan data yang tidak berbeda.

Analisis faktor adalah analisis yang bertujuan untuk mencari faktor-faktor utama yang paling mempengaruhi variabel dependen dari serangkaian uji yang dilakukan atas serangkaian variabel independen sebagai faktornya [27]. Analisis faktor dapat membantu untuk mengetahui variabel mana saja yang sebenarnya sangat dekat atau mirip, serta mana saja dari variabel yang benar-benar berbeda [28].

Sedangkan analisis kualitatif dilakukan dengan cara melakukan uji pakar terhadap variabel-variabel yang telah didapatkan dari hasil studi literatur.

\section{Deskripsi responden}

Responden dalam penelitian ini sebanyak 42 responden yang terdiri dari 12 responden atau $29 \%$ berasal dari pemilik proyek, 5 responden atau $12 \%$ berasal dari konsultan, dan 25 responden atau 59\% berasal dari kontraktor. Dilihat berdasarkan latar belakang pendidikan, 81\% responden berasal dari latar belakang pendidikan Strata 1 (S1), 17\% responden berasal dari latar belakang pendidikan Magister (S2), dan $2 \%$ responden berasal dari latar belakang pendidikan Ahli madya (DIII). Sedangkan dilihat berdasarkan pengalaman kerja, sebanyak 20 responden atau 48\% memiliki pengalaman 5-10 tahun, 10 responden atau $24 \%$ memiliki pengalaman 10-15 tahun, dan 12 responden atau 28\% memiliki pengalaman $>15$ tahun.

\section{Uji validitas dan reliabilitas}

Kuesioner terdiri dari 37 butir pernyataan. Setelah dilakukan uji validitas pakar, uji validitas dan reliabilitas dengan menggunakan program bantu software IBM SPSS Statistic 26.0 maka diperoleh 24 variabel yang valid. Berdasarkan hasil uji reliabilitas terhadap 24 variabel menggunakan program bantu software IBM SPSS Statistic 26.0 diperoleh nilai Cronbach alpha sebesar 0,952 (Lihat Tabel 2) atau > 0,9 . Ini artinya instrumen sangat reliabel.

Tabel 2. Hasil Uji Reliabilitas

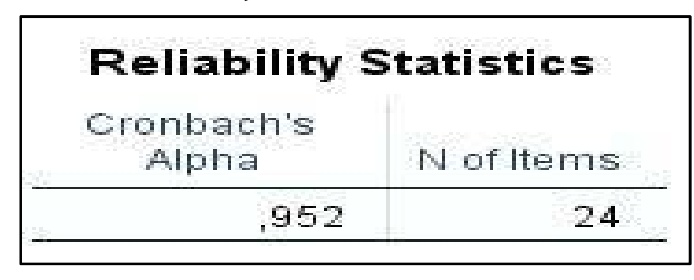

\section{Analisis faktor}

Analisis faktor pada penelitian ini dilakukan terhadap 24 variabel yang telah melalui uji validitas dan reliabilitas. Analisis faktor dilakukan dengan menggunakan program bantu software IBM SPSS Statistic 26.0. Uji analisis faktor dilakukan dengan cara uji KMO MSA (Kaiser-Meyer-Olkin Measure of Sampling Adequacy). Berdasarakan hasil analisis data menunjukkan bahwa analisis faktor dapat dilanjutkan karena nilai KMO MSA $=0,752>0,5$ (Lihat Tabel 3).

Tabel 3. KMO dan Barlett's Test

\begin{tabular}{|c|c|c|}
\hline \multicolumn{2}{|c|}{ KMO and Bartlett's Test } & \multirow[b]{2}{*}{, 852} \\
\hline Kaiser Noyer-dik & of Samoing ragequacy & \\
\hline \multirow{3}{*}{$\begin{array}{l}\text { Baillells Testót } \\
\text { Ephericity }\end{array}$} & Anarex colsouare & 1183,640 \\
\hline & df & 276 \\
\hline & 817 & mo \\
\hline
\end{tabular}

Proses selanjutnya adalah melihat tabel Anti Image Matrices. Adapun hasil output Anti Image Matrices yaitu terdapat hasil output yang memiliki huruf superscript, hal tersebut menunjukkan bahwa data tersebut merupakan data yang menjadi tolak ukur 
valid atau tidaknya fungsi tersebut. Data dianggap valid jika memiliki nilai lebih dari 0,5 dan dinyatakan tidak valid jika memiliki nilai kurang dari 0,5. Dari hasil analisis data menunjukkan, dari semua variabel terdapat 3 (tiga) variabel yang tidak valid, variabel tersebut adalah X7 dengan nilai Anti-image Correlation $=0,369 ;$ X26 dengan nilai Antiimage Correlation $=0,422 ; \mathrm{X} 35$ dengan nilai Anti-image Correlation $=0,418$ dari masingmasing variabel tersebut memiliki nilai Antiimage Correlation < 0,5 sehingga variabel tersebut digugurkan dan tidak digunakan pada analisis berikutnya.

Proses selanjutnya dilakukan dengan uji Communalities. Hasil uji Communalities digunakan untuk mengetahui seberapa besar sebuah variabel dapat menjelaskan faktor.

Berdasarkan Tabel 5 dapat disimpulkan halhal sebagai berikut:

1. Nilai Extraction variabel X2 (Pengguna jasa memberikan perpanjangan waktu sebagai akibat kegagalan Enjinir menerbitkan gambar atau instruksi) = 0,763 . Ini artinya kewajiban pengguna jasa yang sering tidak dipenuhi/dilanggar dapat diwakili oleh variabel X2 sebesar 76,3\%;

2. Nilai Extraction variabel X3 (Pengguna jasa memberikan ganti rugi sejumlah biaya plus keuntungan, yang akan dimasukkan dalam harga kontrak sebagai akibat kegagalan Enjinir menerbitkan gambar atau instruksi) = 0,802 . Ini artinya kewajiban pengguna jasa yang sering tidak dipenuhi/dilanggar dapat diwakili oleh variabel X3 sebesar 80,2\%;

3. Nilai Extraction variabel X5 (Pengguna jasa memberikan perpanjangan waktu sebagai akibat kegagalan pengguna jasa memberikan hak atau penguasaan dalam waktu yang ditentukan) $=0,692$. Ini artinya kewajiban pengguna jasa yang sering tidak dipenuhi/dilanggar dapat diwakili oleh variabel X5 sebesar $69,2 \%$;
4. Nilai Extraction variabel X6 (Pengguna jasa memberikan ganti rugi sejumlah biaya plus keuntungan, yang akan dimasukkan dalam harga kontrak sebagai akibat kegagalan pengguna jasa memberikan hak atau penguasaan dalam waktu yang ditentukan) $=0,849$. Ini artinya kewajiban pengguna jasa yang sering tidak dipenuhi/dilanggar dapat diwakili oleh variabel X6 sebesar 84,9\%;

5. Nilai Extraction variabel X7 (Pengguna jasa harus (jika dia dalam posisi untuk melakukannya) memberikan bantuan yang wajar kepada Kontraktor atas permintaan Kontraktor untuk permohonan izin, lisensi atau persetujuan yang disyaratkan oleh hukum negara) $=0,447$. Ini artinya kewajiban pengguna jasa yang sering tidak dipenuhi/dilanggar dapat diwakili oleh variabel X7 sebesar 44,7\%;

6. Nilai Extraction variabel X9 (Pengguna jasa memberikan perpanjangan waktu akibat kesalahan informasi titik-titik referensi, posisi, ketinggian ukuran) = 0,839 . Ini artinya kewajiban pengguna jasa yang sering tidak dipenuhi/dilanggar dapat diwakili oleh variabel X9 sebesar 83,9\%;

7. Nilai Extraction variabel X10 (Pengguna jasa memberikan ganti rugi sejumlah biaya plus keuntungan yang akan dimasukkan dalam harga kontrak sebagai akibat kesalahan informasi titiktitik referensi, posisi, ketinggian ukuran) $=0,833$. Ini artinya kewajiban pengguna jasa yang sering tidak dipenuhi/dilanggar dapat diwakili oleh variabel X10 sebesar 83,3\%;

8. Nilai Extraction variabel X12 (Pengguna jasa memberikan ganti rugi atas biaya, yang akan dimasukkan ke dalam harga kontrak apabila dan sebatas kontraktor menemui kondisi fisik yang tidak dapat diperkirakan sebelumnya, menyampaikan pemberitahuan) = 0,845 . Ini artinya kewajiban pengguna jasa yang sering tidak 
dipenuhi/dilanggar dapat diwakili oleh variabel X12 sebesar 84,5\%;

9. Nilai Extraction variabel X13 (Pengguna jasa memberikan perpanjangan waktu untuk setiap keterlambatan apabila dan sebatas kontraktor menemui kondisi fisik yang tidak dapat diperkirakan sebelumnya, menyampaikan pemberitahuan) $=0,856$. Ini artinya kewajiban pengguna jasa yang sering tidak dipenuhi/dilanggar dapat diwakili oleh variabel X13 sebesar 85,6\%;

10. Nilai Extraction variabel X14 (Bilamana kontraktor mengalami keterlambatan dan/atau menanggung biaya karena mengikuti instruksi tersebut (Kontraktor harus melakukan tindakan pengamanan untuk mencegah personil kontraktor atau orang lain memindahkan atau merusak temuantemuan tersebut), pengguna jasa memberikan perpanjangan waktu) = 0,809 . Ini artinya kewajiban pengguna jasa yang sering tidak dipenuhi/dilanggar dapat diwakili oleh variabel X14 sebesar 80,9\%;

11. Nilai Extraction variabel X15 (Bilamana kontraktor mengalami keterlambatan dan/atau menanggung biaya karena mengikuti instruksi tersebut (Kontraktor harus melakukan tindakan pengamanan untuk mencegah personil kontraktor atau orang lain memindahkan atau merusak temuantemuan tersebut), pengguna jasa memberikan ganti rugi atas biaya yang akan dimasukkan dalam harga kontrak) $=0,835$. Ini artinya kewajiban pengguna jasa yang sering tidak dipenuhi/dilanggar dapat diwakili oleh variabel X15 sebesar 83,5\%;

12. Nilai Extraction variabel X16 (Pengguna jasa memberikan perpanjangan waktu jika pengujian ditunda oleh (atas nama) pengguna jasa) $=0,862$. Ini artinya kewajiban pengguna jasa yang sering tidak dipenuhi/dilanggar dapat diwakili oleh variabel X16 sebesar $86,2 \%$;
13. Nilai Extraction variabel X17 (Pengguna jasa memberikan ganti rugi atas setiap biaya ditambah dengan keuntungan, yang akan ditambahkan ke dalam harga kontrak jika pengujian ditunda oleh (atas nama) pengguna jasa) $=0,913$. Ini artinya kewajiban pengguna jasa yang sering tidak dipenuhi/dilanggar dapat diwakili oleh variabel X17 sebesar 91,3\%;

14. Nilai Extraction variabel X20 (Pengguna jasa memberikan perpanjangan waktu penyelesaian akibat kelainan keadaan cuaca yang sangat buruk) $=0,810$. Ini artinya kewajiban pengguna jasa yang sering tidak dipenuhi/dilanggar dapat diwakili oleh variabel X20 sebesar 81,0\%;

15. Nilai Extraction variabel X21 (Pengguna jasa memberikan perpanjangan waktu penyelesaian akibat instruksi untuk menghentikan kemajuan suatu bagian pekerjaan atau seluruh pekerjaan) = 0,813 . Ini artinya kewajiban pengguna jasa yang sering tidak dipenuhi/dilanggar dapat diwakili oleh variabel X21 sebesar 81,3\%;

16. Nilai Extraction variabel X22 (Pengguna jasa memberikan ganti rugi atas setiap biaya, yang akan dimasukkan ke dalam harga kontrak akibat instruksi untuk menghentikan kemajuan suatu bagian pekerjaan atau seluruh pekerjaan) = 0,726 . Ini artinya kewajiban pengguna jasa yang sering tidak dipenuhi/dilanggar dapat diwakili oleh variabel X22 sebesar 72,6\%;

17. Nilai Extraction variabel X25 (Pengguna jasa mensetujui atau menentukan tarif atau harga sementara apabila item tersebut tidak terdapat dalam kontrak) $=0,645$. Ini artinya kewajiban pengguna jasa yang sering tidak dipenuhi/dilanggar dapat diwakili oleh variabel X25 sebesar 64,5\%;

18. Nilai Extraction variabel X26 (Pengguna jasa mensetujui atau menentukan bayaran (fee) kepada kontraktor atas usulan yang disampaikan oleh 
kontraktor yang memberikan manfaat (biaya, mutu, waktu) bagi pengguna jasa) $=0,528$. Ini artinya kewajiban pengguna jasa yang sering tidak dipenuhi/dilanggar dapat diwakili oleh variabel X26 sebesar 52,8\%;

19. Nilai Extraction variabel X29 (Pengguna jasa menerbitkan Berita Acara Pembayaran Sementara (28 hari setelah menerima pernyataan tagihan dan dokumen pendukung)) $=0,699$. Ini artinya kewajiban pengguna jasa yang sering tidak dipenuhi/dilanggar dapat diwakili oleh variabel X29 sebesar 69,9\%;

20. Nilai Extraction variabel X30 (Pengguna jasa membayar jumlah yang disahkan dalam setiap Berita Acara Pembayaran Sementara (56 hari setelah menerima pernyataan tagihan dan dokumen pendukung)) $=0,906$. Ini artinya kewajiban pengguna jasa yang sering tidak dipenuhi/dilanggar dapat diwakili oleh variabel X30 sebesar 90,6\%;

21. Nilai Extraction variabel X31 (Pengguna jasa memberikan ganti rugi biaya bunga yang digabungkan secara bulanan pada pembayaran yang tertunda selama terjadinya keterlambatan pembayaran) $=0,852$. Ini artinya kewajiban pengguna jasa yang sering tidak dipenuhi/dilanggar dapat diwakili oleh variabel X31 sebesar 85,2\%;

22. Nilai Extraction variabel X33 (Pengguna jasa tepat waktu dalam dalam menerbitkan Berita Acara Pembayaran Akhir (28 hari setelah menerima tagihaan akhir dan pernyataan pembebasan dari kewajiban)) $=0,774$. Ini artinya kewajiban pengguna jasa yang sering tidak dipenuhi/dilanggar dapat diwakili oleh variabel X33 sebesar 77,4\%;

23. Nilai Extraction variabel X35 (Pengguna jasa menerbitkan pemberitahuan untuk mengakhiri kontrak jika kontraktor gagal melaksanakan kewajiban dalam kontrak (Dalam kejadian dan keadaan ini, pengguna jasa dapat, setelah menyampaikan pemberitahuan dalam jangka 14 hari kepada kontraktor, memutuskan kontrak dan mengeluarkan kontraktor dari lapangan)) $=0,590$. Ini artinya kewajiban pengguna jasa yang sering tidak dipenuhi/dilanggar dapat diwakili oleh variabel X35 sebesar 59,0\%;

24. Nilai Extraction variabel X36 (Pengguna jasa memberikan perpanjangan waktu penyelesaian pekerjaan akibat dari penghentian pekerjaan oleh kontraktor yang dikarenakan pengguna jasa gagal untuk menerbitkan dan mensahkan Berita Acara Pembayaran Sementara, keterlambatan pembayaran progres pekerjaan) $=0,894$. Ini artinya kewajiban pengguna jasa yang sering tidak dipenuhi/dilanggar dapat diwakili oleh variabel X36 sebesar 89,4\%.

Tabel 4. Communalities

\begin{tabular}{llc}
\hline & \multicolumn{2}{c}{ Communalities } \\
\hline & Initial & Extraction \\
\hline X2 & 1.000 & 0.763 \\
\hline X3 & 1.000 & 0.802 \\
\hline X6 & 1.000 & 0.692 \\
\hline X7 & 1.000 & 0.849 \\
\hline X9 & 1.000 & 0.447 \\
\hline X10 & 1.000 & 0.839 \\
\hline X12 & 1.000 & 0.833 \\
\hline X13 & 1.000 & 0.845 \\
\hline X14 & 1.000 & 0.856 \\
\hline X15 & 1.000 & 0.809 \\
\hline X16 & 1.000 & 0.835 \\
\hline X17 & 1.000 & 0.862 \\
\hline X20 & 1.000 & 0.913 \\
\hline X21 & 1.000 & 0.810 \\
\hline X22 & 1.000 & 0.813 \\
\hline X25 & 1.000 & 0.726 \\
\hline X26 & 1.000 & \\
\hline & & 0.645 \\
\hline
\end{tabular}




\begin{tabular}{lcc}
\hline & \multicolumn{2}{c}{ Communalities } \\
\hline & Initial & Extraction \\
\hline $\mathrm{X} 29$ & 1.000 & 0.699 \\
\hline $\mathrm{X} 30$ & 1.000 & 0.906 \\
\hline $\mathrm{X} 31$ & 1.000 & 0.852 \\
\hline $\mathrm{X} 33$ & 1.000 & 0.774 \\
\hline $\mathrm{X} 35$ & 1.000 & 0.590 \\
\hline $\mathrm{X} 36$ & 1.000 & 0.894 \\
\hline
\end{tabular}

Tabel 5. Dampak Tidak Dipenuhinya Kewajiban Pengguna Jasa

\begin{tabular}{|c|c|}
\hline Variabel & Dampak \\
\hline \multirow[t]{4}{*}{ X16 } & $\begin{array}{l}\text { 1. Keterlambatan waktu pengujian } \\
\text { akan berdampak pada durasi } \\
\text { pekerjaan selanjutnya }\end{array}$ \\
\hline & $\begin{array}{l}\text { 2. Jadwal pelaksanaan pekerjaan } \\
\text { akan mundur atau tidak sesuai } \\
\text { dengan jadwal yang telah } \\
\text { ditentukan sebelumnya }\end{array}$ \\
\hline & $\begin{array}{l}\text { 3. Bertambahnya biaya akibat } \\
\text { jadwal pelaksanaan pekerjaan } \\
\text { yang mundur dari jadwal yang } \\
\text { ditentukan sebelumnya }\end{array}$ \\
\hline & $\begin{array}{l}\text { 4. Penyedia jasa berpotensi } \\
\text { terkena denda yang di ajukan } \\
\text { oleh pengguna jasa akibat } \\
\text { mundurnya jadwal pelaksanaan } \\
\text { proyek }\end{array}$ \\
\hline \multirow[t]{4}{*}{$\mathrm{X} 17$} & $\begin{array}{l}\text { 1. Penyedia jasa akan } \\
\text { mengeluarkan biaya yang tidak } \\
\text { diperkirakan sebelumnya }\end{array}$ \\
\hline & $\begin{array}{l}\text { 2. Bertambahnya biaya overhead } \\
\text { sehingga dapat memperkecil } \\
\text { keuntungan dari penyedia jasa }\end{array}$ \\
\hline & $\begin{array}{l}\text { 3. Pembengkakan biaya (cost } \\
\text { overrun), sehingga } \\
\text { menimbulkan kerugian bagi } \\
\text { pihak penyedia jasa }\end{array}$ \\
\hline & $\begin{array}{l}\text { 4. Berpotensi } \\
\text { dispute }\end{array}$ \\
\hline \multirow[t]{5}{*}{ X30 } & $\begin{array}{l}\text { 1. Terjadi permasalahan cash flow } \\
\text { pada penyedia jasa }\end{array}$ \\
\hline & $\begin{array}{l}\text { 2. Gagal bayar kontraktor utama } \\
\text { kepada sub-kontraktor }\end{array}$ \\
\hline & $\begin{array}{l}\text { 3. Akan menurunkan performa } \\
\text { kerja penyedia jasa }\end{array}$ \\
\hline & $\begin{array}{l}\text { 4. Timbulnya klaim financing } \\
\text { charges oleh penyedia jasa } \\
\text { kepada pengguna jasa }\end{array}$ \\
\hline & $\begin{array}{l}\text { 5. Berpotensi } \\
\text { dispute }\end{array}$ \\
\hline \multirow[t]{4}{*}{ X31 } & $\begin{array}{l}\text { 1. Terjadi permasalahan cash flow } \\
\text { pada penyedia jasa akibat } \\
\text { menanggung biaya bunga } \\
\text { pinjaman bank }\end{array}$ \\
\hline & $\begin{array}{l}\text { 2. Pembengkakan biaya (cost } \\
\text { overrun), }\end{array}$ \\
\hline & $\begin{array}{l}\text { menimbulkan kerugian bagi } \\
\text { pihak penyedia jasa }\end{array}$ \\
\hline & $\begin{array}{l}\text { 3. Akan menurunkan performa } \\
\text { kerja penyedia jasa }\end{array}$ \\
\hline
\end{tabular}

Berdasarkan nilai extraction pada 24 (dua puluh empat) variabel di atas, diperoleh kesimpulan bahwa terdapat 5 (lima) variabel dominan. Variabel tersebut adalah X17, X30, X36, X16, X31, dimana masingmasing memiliki nilai extraction pada variabel X17 memiliki nilai extraction terbesar yaitu 0,913 atau 91,3\% disusul dengan variabel X30 sebesar 0,906 atau $90,6 \%$, variabel X36 sebesar 0,894 atau $89,4 \%$, variabel X16 sebesar 0,862 atau $86,2 \%$, dan X31 sebesar 0,852 atau 85,2\%.

\section{Analisis kualitatif}

Tahapan selanjutnya dari penelitian ini adalah melakukan analisis dampak yang akan terjadi apabila kewajiban pengguna jasa sesuai kontrak tidak dipenuhi. Analisis ini dilakukan dengan cara menyebarkan kuisioner kepada responden yang telah ditentukan dan selanjutnya jawaban yang dituliskan oleh responden dilakukan analisis. Hal ini bertujuan untuk mendapatkan jawaban yang sesuai dengan pernyataan yang ada di dalam kuisioner.

Dari keseluruhan variabel yang telah diuji, ditemukan 5 (lima) variabel yang paling dominan. Variabel dominan tersebut dipilih berdasarkan hasil studi literatur, validasi pakar dan selanjutnya dilakukan analisis statistik. Adapun dampak yang akan timbul dari 5 (lima) variabel dominan tersebut apabila tidak dipenuhi oleh pihak pengguna jasa menurut responden dapat dilihat pada Tabel 5 berikut. 


\begin{tabular}{|c|c|}
\hline Variabel & Dampak \\
\hline & $\begin{array}{l}\text { 4. Berpotensi } \\
\text { dispute }\end{array}$ \\
\hline \multirow[t]{4}{*}{ X36 } & $\begin{array}{l}\text { 1. Jadwal pelaksanaan pekerjaan } \\
\text { akan mundur atau tidak sesuai } \\
\text { dengan jadwal yang telah } \\
\text { ditentukan sebelumnya }\end{array}$ \\
\hline & $\begin{array}{l}\text { 2. Bertambahnya biaya akibat } \\
\text { jadwal pelaksanaan pekerjaan } \\
\text { yang mundur dari jadwal yang } \\
\text { ditentukan sebelumnya }\end{array}$ \\
\hline & $\begin{array}{l}\text { 3. Penyedia jasa berpotensi } \\
\text { terkena denda yang di ajukan } \\
\text { oleh pengguna jasa akibat } \\
\text { mundurnya jadwal pelaksanaan } \\
\text { proyek }\end{array}$ \\
\hline & $\begin{array}{l}\text { 4. Berpotensi } \\
\text { dispute }\end{array}$ \\
\hline
\end{tabular}

\section{KESIMPULAN}

Berdasarkan hasil analisis yang telah dilakukan, dapat disimpulkan hal-hal sebagai berikut:

1. Kewajiban pengguna jasa sesuai kontrak yang tidak dipenuhi adalah:

a) Pengguna jasa memberikan ganti rugi atas setiap biaya ditambah dengan keuntungan, yang akan ditambahkan ke dalam harga kontrak jika pengujian ditunda oleh (atas nama) pengguna jasa

b) Pengguna jasa membayar jumlah yang disahkan dalam setiap Berita Acara Pembayaran Sementara (56 hari setelah menerima pernyataan tagihan dan dokumen pendukung)

c) Pengguna jasa memberikan perpanjangan waktu penyelesaian pekerjaan akibat dari penghentian pekerjaan oleh kontraktor yang dikarenakan pengguna jasa gagal untuk menerbitkan dan mensahkan Berita Acara Pembayaran Sementara, keterlambatan pembayaran progres pekerjaan

d) Pengguna jasa memberikan perpanjangan waktu jika pengujian ditunda oleh (atas nama) pengguna jasa e) Pengguna jasa memberikan ganti rugi biaya bunga yang digabungkan secara bulanan pada pembayaran yang tertunda selama terjadinya keterlambatan pembayaran.

2. Dampak tidak dipenuhinya kewajiban pengguna jasa sesuai kontrak adalah:

a) Penyedia jasa akan mengeluarkan biaya yang tidak diperkirakan sebelumnya, Bertambahnya biaya overhead sehingga dapat memperkecil keuntungan dari penyedia jasa, Pembengkakan biaya (cost overrun), sehingga menimbulkan kerugian bagi pihak penyedia jasa, Berpotensi menimbulkan dispute

b) Terjadi permasalahan cash flow pada penyedia jasa, Gagal bayar kontraktor utama kepada sub-kontraktor, Akan menurunkan performa kerja penyedia jasa, Timbulnya klaim financing charges oleh penyedia jasa kepada pengguna jasa, Berpotensi menimbulkan dispute

c) Jadwal pelaksanaan pekerjaan akan mundur atau tidak sesuai dengan jadwal yang telah ditentukan sebelumnya, Bertambahnya biaya akibat jadwal pelaksanaan pekerjaan yang mundur dari jadwal yang ditentukan sebelumnya, Penyedia jasa berpotensi terkena denda yang di ajukan oleh pengguna jasa akibat mundurnya jadwal pelaksanaan proyek, Berpotensi menimbulkan dispute

d) Keterlambatan waktu pengujian akan berdampak pada durasi pekerjaan selanjutnya, Jadwal pelaksanaan pekerjaan akan mundur atau tidak sesuai dengan jadwal yang telah ditentukan sebelumnya, Bertambahnya biaya akibat jadwal pelaksanaan pekerjaan yang mundur dari jadwal yang ditentukan sebelumnya, Penyedia jasa berpotensi terkena denda yang di ajukan oleh pengguna jasa akibat 
mundurnya jadwal pelaksanaan proyek

\section{DAFTAR PUSTAKA}

[1] Badan Pusat Statistik. 2019. Indikator Konstruksi Triwulan I - 2019. Jakarta: Sub-direktorat Statistik Konstruksi.

[2] Purba, H dan Prastowo, Y. 2020. Potential Risk Occurring in FIDIC Contract Construction Project: A Literature Review. Advance Researches in Civil Engineering. Vol. 2 (1). Hal: 1-12

[3] Flanagan R, and Norman G. (1993). Risk Management and Construction. Oxford. UK. Blackwell Science Ltd.

[4] Bu-Qammaz, A. S., Dikmen, I., \& Birgonul, M. T. (2009). "Risk Assessment of International Construction Projects Using the Analytic Network Process". Canadian Journal of Civil Engineering, Vol 36. Hal 1.170-1.181

[5] Siraj, B Nasir., Aminah R Fayek. (2019). "Risk Identification and Common Risk in Construction: Literature Review and Content Analysis". J. Constr. Eng. Manage. 145 (9): 03119004. https://ascelibrary.org/doi/pdf/10.1 061/\%28ASCE\%29C0.19437862.0001685

[6] Galih, A dan Hardjomuljadi, Sarwono. (2013). "Analisis Faktor Penyebab Klaim Pada Proyek Konstruksi Yang Menggunakan FIDIC Conditions of Contract for Plant and Design Build". Jurnal Konstruksia. Vol. 5 (1).

[7] Shadid, Mosab Sael Rushdi. (2015). Construction Claim Management in United Arab Emirates Construction Industry. Eastern Mediterranean University: Gazimaguza, North Cyprus

[8] Rivai, Ruslan. 2018. Kata Sambutan: Lembaga Pengembangan Jasa Konstruksi (LPJK) Nasional dalam Mascruchiyah, $\quad$ Nieke. 2018. Penyelesaian Sengketa Kontrak Kerja
Konstruksi Melalui Arbitrase \& APS. PT Raja Grafindo Persada: Depok.

[9] Hardjomuljadi, Sarwono. 2014. Permasalahan Klaim Konstruksi Di Proyek Institusi Pemerintah. Seminar Konstruksi Indonesia. Jakarta: 6 November 2014

[10] Soeharto, Iman. (1995). Manajemen Proyek Dari Konseptual Sampai Operasional. Erlangga. Jakarta

[11] Ervianto, I. W. (2005). Manajemen Proyek Konstruksi Edisi Revisi. Andi. Yogyakarta

[12] Hegazy, Tarek. (2003). ComputerBased Construction in Project Management. Prentice Hall, New Jersey

[13] Gifis, Steven. H. 1984. Law Dictionary dalam Masruchiyah, Nieke. 2018. Penyelesaian Sengketa Kontrak Kerja Konstruksi Melalui Arbitrase \& APS. PT. Raja Grafindo Persada: Depok

[14] Pemerintah Indonesia. 2003. Keputusan Presiden Republik Indonesia No. 80 Tahun 2003 tentang pedoman pelaksanaan pengadaan barang/jasa pemerintah. Lembaran Negara RI Tahun 2003 No. 80. Jakarta: Sekertariat Negara.

[15] Pemerintah Indonesia. 2000. Peraturan Pemerintah Republik Indonesia No. 29 Tahun 2000 tentang penyelenggaraan jasa konstruksi. Lembaran Negara RI Tahun 2000 No. 29. Jakarta: Sekertariat Negara.

[16] Hardjomuljadi, Sarwono. 2014. Buku Kesatu: Pengantar Kontrak Konstruksi FIDIC Conditions of Contract. Bandung: Logoz Publishing.

[17] Tay, Chaterine Swee Kian and Tang See Chim. 2004. Contract Law. Marshall Cavendish International.

[18] Garner, Brian A. 2004. Black's Law Dictionary, Tenth Edition, Thomson Reuters, St. Paul-Minnesota, dalam Hardjomuljadi, Sarwono. 2014. Buku Kesatu: Pengantar Kontrak Konstruksi 
FIDIC Condition of Contract. Bandung: Logoz Publishing.

[19] Bubshait, A Abdulaziz and Soliman, A Almohawis. (1994). "Evaluating the General Conditions of a Construction Contract". International Journal of Project Management . Vol 12 (3). Hal 133-136.

[20] Fédération Internationale des Ingenierus-Conseils. FIDIC. 1999. Condition of Contract for Construction First Edition. FIDIC.

[21] Hardjomuljadi, Sarwono; Abdulkadir, Ariono; Takei, Masaru. 2006. Strategi Klaim Konstruksi Berdasarkan FIDIC Condition of Contract. Pola Grade. Jakarta.

[22] Martin, Elizabeth A and Law, Jonathan. 2006. Oxford Dictionary of Law. Oxford University Press. New York.

[23] Hardjomuljadi, Sarwono. (2014). "Factor Analysis on Causal of Construction Claims and Disputes in Indonesia (with Reference to the Construction of Hydroelectric Power Project in Indonesia)". International Journal of Applied Engineering Research. Vol. 9 (22). Hal: 12.42112.445 .

[24] Neuman, W. L. 2014. Social Research Methods: Qualitative and Quantitative Approaches; Relevance of Social Research, Vol: 8.

[25] Sugiyono. (2010). Metodologi Penelitian Pendidikan Pendekatan Kuantitatif, Kualitatif Dan R\&D. Bandung: Alfabeta.

[26] Sugiyono. (2017). Metode Penelitian \& Pengembangan Untuk Bidang: Pendidikan, Manajemen, Sosial, Teknik. Bandung: Alfabeta.

[27] Santoso, S. (2014). SPSS20 Pengolahan Data Statistik di Era Informasi. Jakarta: PT. Alex Media Komputindo.

[28] Nisfianoor, Muhammad. (2009). Pendekatan Statistika Modern Untuk Ilmu Sosial. Jakarta: Salemba Humanika. 
